\title{
Oxidant and antioxidant compounds, gas exchange and growth of young Schizolobium parahyba var. amazonicum plants under high boron and calcium concentrations
}

\author{
Daihany Moraes Callegari, Bianca do Carmo Silva, Pêola Reis de Sousa, Allan Klynger da Silva Lobato, \\ Elaine Maria Silva Guedes Lobato*
}

Universidade Federal Rural da Amazônia. Paragominas, Pará, Brazil

\section{A B S T R A C T}

\begin{abstract}
Boron (B) and Calcium (Ca) unbalance in plants during early stages can generate oxidative stress and consequently to interfere negatively on growth and quality of seedlings. This study aims to evaluate the gas exchange and measure the biochemical responses, responding how high concentrations of B and $\mathrm{Ca}$ can affect the growth and quality of young Schizolobium parahyba plants. The experimental design used was completely randomised with four treatments [1-25 $\mu \mathrm{M} \mathrm{B}+5 \mathrm{mM} \mathrm{Ca}$ (control); $2-25 \mu \mathrm{M} \mathrm{B}+50 \mathrm{mM} \mathrm{Ca}$ (Ca high); 3- 250 $\mu \mathrm{M}$ $\mathrm{B}+5 \mathrm{mM} \mathrm{Ca}$ (B high) and $4-250 \mu \mathrm{M} \mathrm{B}+50 \mathrm{mM}$ Ca (B and Ca high)]. Negative impacts on gas exchange, photosynthetic pigments and total glutathione were obtained, besides increases in hydrogen peroxide and electrolyte leakage were verified in plants treated with $B$ and $\mathrm{Ca}$ high, indicating oxidative stress. Thus, application $250 \mu \mathrm{M} \mathrm{B}$ combined with $50 \mathrm{mM}$ Ca promoted disorders in plant metabolism, decreasing the growth and quality of young Schizolobium parahyba plants.
\end{abstract}

Keywords: Antioxidant metabolism; Gas exchange; Macronutrient; Micronutrient; Reactive oxygen species

\section{INTRODUCTION}

Paricá (Schizolobium parabyba var. amazonicum (Huber ex Ducke) Barneby) is a forestry species with large economic potential and there is demand for uniform seedlings and with adequate quality aiming to improve the assimilation of nutrients, more specifically boron (B) and calcium (Ca).

$\mathrm{B}$ is a micronutrient essential for growth and development in higher plants, mainly during the early stages of growth, because participates formation of the cell wall, root elongation, carbon metabolism and cell membrane integrity (Martinez-Cuenca et al., 2015). In addition, Ca is a macronutrient that acts on the cell wall structure, during cell division, and as secondary messenger during stomatal closing in plants (White and Broadley, 2003; Dayod et al., 2010).

Nutritional imbalances frequently cause oxidative stress, which result in membrane damages and cell death (Kaya and Ashraf, 2015). B and Ca under inadequate levels affect the biochemical and physiological behaviours, mainly during early stages of plant growth, with consequences on the establishment, quality and survival of seedlings in field conditions (Lautner et al., 2007; Lehto et al., 2010). In Vitis vinifera excess $\mathrm{B}$ promoted oxidative stress due to high production of hydrogen peroxide $\left(\mathrm{H}_{2} \mathrm{O}_{2}\right)$ (Gunes et al., 2006). On other hand, higher plants can produce antioxidant compounds, such as total glutathione (GSH) and ascorbate (ASC), which it act during the elimination of reactive oxygen species (ROS) (Molassiotis et al., 2006). Gas exchanges also are negatively affected in Ocimum basilicum plants treated with B high (Landi et al., 2013a) and in Lysionotus pauciflorus and Boea bygrometrica exposed to Ca high (Li et al., 2014).

The appropriate balance to $\mathrm{B}$ and $\mathrm{Ca}$ in forest species may be decisive for the better growth and development of seedlings, which these elements have an intrinsic

\footnotetext{
*Corresponding author:

Elaine Maria Silva Guedes Lobato, Rodovia PA 256, Paragominas, Pará, Brazil. Universidade Federal Rural da Amazônia.

Phone: +55-91-982612598. Fax: +55-91-982612598. E-mail: allanllobato@yahoo.com.br
} 
relationship in plant metabolism. Our hypothesis is that the $\mathrm{B}$ and $\mathrm{Ca}$ unbalance in $S$. parabyba plants during early stages can generate oxidative stress and consequently to interfere negatively on growth and quality of seedlings.

This study aims to evaluate the gas exchange and measure the biochemical responses, responding how high concentrations of $\mathrm{B}$ and $\mathrm{Ca}$ can affect the growth and quality of young Schizolobium parabyba plants.

\section{MATERIALS AND METHODS}

\section{Location and growth conditions}

The experiment was carried out in the Universidade Federal Rural da Amazônia located in Paragominas, Brazil $\left(2^{\circ} 55^{\prime} \mathrm{S}\right.$ and $\left.47^{\circ} 34^{\prime} \mathrm{W}\right)$. Seedlings were grown in a greenhouse under environmental control to temperature and humidity, the minimum, maximum, and median temperatures were $24^{\circ} \mathrm{C}, 33^{\circ} \mathrm{C}$, and $27.5^{\circ} \mathrm{C}$, respectively, and relative humidity of $65 / 85 \%$.

\section{Plants, containers and acclimation}

Seeds of $S$. parabyba were sterilized for $3 \mathrm{~min}$ in a $1 \%$ of sodium hypochlorite $(\mathrm{NaCIO})$, being scarified to increase speed of the germination. These seeds were placed into 1.2-L containers to germinate $(0.15 \mathrm{~m}$ in height and $0.10 \mathrm{~m}$ in diameter) occupied with substrate mixture composed of sand and vermiculite in a 3:1 proportion. The ionic force started at $25 \%$, and it was reformed to $50 \%$ and $100 \%$ at regular intervals over three days. Subsequently these periods, the nutritive solution persisted with the total ionic force $(100 \%)$ from $20^{\text {th }}$ until $35^{\text {th }}$ day after experiment implementation.

\section{Experimental design}

The experimental design used was completely randomised with four treatments [1 - $25 \mu \mathrm{M} \mathrm{B}+5 \mathrm{mM} \mathrm{Ca}$ (control); $2-25 \mu \mathrm{M} \mathrm{B}+50 \mathrm{mM} \mathrm{Ca}$ (Ca high); 3- $250 \mu \mathrm{M} \mathrm{B}+5 \mathrm{mM}$ $\mathrm{Ca}$ (B high) and $4-250 \mu \mathrm{MB}+50 \mathrm{mM} \mathrm{Ca}$ (B and Ca high)]. The $\mathrm{B}$ and $\mathrm{Ca}$ concentrations were chosen in agreement with Hoagland and Arnon (1950). This study used five replicates and 20 experimental units, being one plant per container considered one unit experimental.

\section{Treatments and nutrient solution}

One young plant was preserved in each pot, during plant conduction. The seedlings were supplied with nutrient solution containing the following macronutrients and micronutrients: $5.71 \mathrm{mM} \mathrm{KNO}_{3}, 2.85 \mathrm{mM} \mathrm{Ca}\left(\mathrm{NO}_{3}\right)_{2} \cdot 4 \mathrm{H}_{2} \mathrm{O}$, $1.43 \mathrm{mM} \mathrm{NH}_{4} \mathrm{H}_{2} \mathrm{PO}_{4}, 3.21 \mathrm{mM} \mathrm{MgSO} \cdot 7 \mathrm{H}_{2} \mathrm{O}, 0.71$ $\mathrm{mM} \mathrm{KCl}, 1.42 \mathrm{mM} \mathrm{KH} \mathrm{PO}_{4}, 1.42 \mu \mathrm{M} \mathrm{MnSO}_{4} \cdot \mathrm{H}_{2} \mathrm{O}$, $1.42 \mu \mathrm{M} \mathrm{ZnSO} \cdot 7 \mathrm{H}_{2} \mathrm{O}, 0.35 \mu \mathrm{M} \mathrm{CuSO}_{4} \cdot 5 \mathrm{H}_{2} \mathrm{O}, 0.35 \mu \mathrm{M}$ $\mathrm{NaMoO}_{4} \cdot 5 \mathrm{H}_{2} \mathrm{O}, 215 \mu \mathrm{M}$ NaEDTAFe $3 \mathrm{H}_{2} \mathrm{O}$. To simulate $\mathrm{B}$ and $\mathrm{Ca}$ treatments, $\mathrm{H}_{3} \mathrm{BO}_{3}$ was used at concentrations of
$25 \mu \mathrm{M}$ and $250 \mu \mathrm{MB}$, while $\mathrm{CaCl}_{2}$ was used at concentrations 5 and $50 \mathrm{mM}$ Ca during 25 days ( $35^{\text {th }}$ day until $60^{\text {th }}$ day). On $60^{\text {th }}$ day after experiment implementation, all plants were physiologically evaluated and leaf, stem and root tissues were collected for biochemical analysis.

\section{Evaluation of gas exchange}

The net photosynthetic rate $\left(P_{N}\right)$, transpiration rate $(E)$, stomatal conductance $\left(g_{s}\right)$, and intercellular $\mathrm{CO}_{2}$ concentration $\left(C_{\mathrm{i}}\right)$ were measured on the adaxial surface of fully expanded leaves that were collected from the middle region of the plant using an infrared gas analyser (model $\mathrm{LCPro}^{+}$; ADC BioScientific). The efficiency in the instantaneous use of water (WUE $=P_{\mathrm{N}} / E$ ) was estimated according to Ma et al. (2004). To instantaneous carboxylation efficiency $\left(P_{\mathrm{N}} / C_{\mathrm{i}}\right)$ was used the formula described previously by Aragão et al. (2012). Gas exchange was mensured in all plants under constant conditions of $\mathrm{CO}_{2}$ concentration, photosynthetically active radiation, air-flow rate and temperature in a chamber set at $360 \mu \mathrm{mol} \mathrm{mol}{ }^{-1} \mathrm{CO}_{2}, 800 \mu \mathrm{mol}$ photons $\mathrm{m}^{-2} \mathrm{~s}^{-1}, 300 \mu \mathrm{mol}$ $\mathrm{s}^{-1}$ and $28^{\circ} \mathrm{C}$, respectively, between 10:00 and 12:00 h.

\section{Determination of photosynthetic pigments}

The chlorophyll and carotenoid determinations were performed using $40 \mathrm{mg}$ of leaf tissue. The samples were homogenised in the dark with $8 \mathrm{~mL}$ of $90 \%$ methanol (Nuclear). The homogenate was centrifuged at $6.000 \times \mathrm{g}$ for $10 \mathrm{~min}$ at $5^{\circ} \mathrm{C}$. The supernatant was removed, and the chlorophyll $a(\mathrm{Chl} a)$ and $b(\mathrm{Chl} b)$, and carotenoid (Car) and total chlorophyll (total $\mathrm{Chl}$ ) contents were quantified using a spectrophotometer (model UV-M51; Bel Photonics) according to the methodology of Lichtenthaler and Buschmann (2001).

\section{Extraction and determination of oxidant and antioxidant compounds}

The extraction of Hydrogen peroxide $\left(\mathrm{H}_{2} \mathrm{O}_{2}\right)$, total glutathione (GSH), and ascorbate (ASC) from leaf and root tissues was made using the methodology described by $\mathrm{Wu}$ et al. (2006). To measure $\mathrm{H}_{2} \mathrm{O}_{2}$ was used the methodology by Velikova et al. (2000). To total GSH was used methodology described by Wu et al. (2006). The methodology to measure the ASC in the plant tissue was defined by Cakmak and Marschner (1992).

\section{Determination of electrolyte leakage}

Electrolyte leakage (EL) was measured using the method described by Gong et al. (1998) with minor modifications.

\section{Growth and quality of seedlings}

The height and stem diameter of the seedlings were measured 60 days after experiment implementation. The plant material was separated in leaves, stem and roots, 
washed with deionised water (Malavolta et al., 1997). Leaves, roots and stems were then dried in a forced circulation oven at $65^{\circ} \mathrm{C}$ until constant weight to determine their dry matters. The Dickson quality index (DQI) was determined using the equation: $\mathrm{DQI}=\mathrm{TDM} /[(\mathrm{H} / \mathrm{SD})+$ $(\mathrm{SDM} / \mathrm{RDM})]$. Where: TDM = total dry matter $(\mathrm{g}), \mathrm{SD}$ = stem diameter $(\mathrm{mm}), \mathrm{H}=$ height $(\mathrm{cm}), \mathrm{SDM}=$ shoot dry matter $(\mathrm{g}), \mathrm{RDM}=$ root dry matter $(\mathrm{g})$. For analysis of concentration and accumulation of $\mathrm{B}$ and $\mathrm{Ca}$ in plant tissues, the samples were extracted by dry digestion (incineration) for the analysis of $\mathrm{B}$ and nitric perchloric digestion for the $\mathrm{Ca}$. And determination $\mathrm{B}$ was according to the colorimetric method and $\mathrm{Ca}$ were determined by atomic absorption spectrophotometry, both methods described by Malavolta et al. (1997).

\section{Data analysis}

The data were subjected to one way analysis of variance, and significant differences between the means were determined using the Scott-Knott test at a probability level of $5 \%$, being chosen this test due to your precision, if compared other statistical tests. The procedure involved in Scott-Knott test to determinate the significance between treatments is based on maximum likelihood estimator, and not LSD as in other tests (Duncan, Dunnett, SNK and Tukey). Standard deviations were determined for each treatment. The statistical analyses were performed with Assistat software.

\section{RESULTS}

\section{$\mathrm{B}$ and $\mathrm{Ca}$ contents}

The higher availability of $\mathrm{B}$ and $\mathrm{Ca}(250 \mu \mathrm{M} \mathrm{B}+50 \mathrm{mM}$ $\mathrm{Ca}$ ) was responsible for significant increases in content and accumulation $\mathrm{B}$ in leaf (Table 1). In relation to $\mathrm{B}$ content, the treatment $250 \mu \mathrm{M} \mathrm{B}+5 \mathrm{mM}$ Ca promoted higher B content in stem and root. On Ca content, the treatment with high B and $\mathrm{Ca}(250 \mu \mathrm{M} \mathrm{B}+50 \mathrm{mM} \mathrm{Ca})$ presented not differences to leaf and stem, comparison with control treatment $(25 \mu \mathrm{M} \mathrm{B}+5 \mathrm{mM} \mathrm{Ca})$. The treatment with $250 \mu \mathrm{M} \mathrm{B}+50 \mathrm{mM}$ Ca caused a significant increase (Table 1) in the Ca accumulation in the leaf (20\%), stem $(39 \%)$ and root $(15 \%)$, respectively.

Consequences of $B$ and $\mathrm{Ca}$ supplies on $\mathrm{H}_{2} \mathrm{O}_{2}$ and $\mathrm{EL}$ In $\mathrm{H}_{2} \mathrm{O}_{2}$ were showed significant increases promoted by the $\mathrm{B}$ and $\mathrm{Ca}$ supplies (Fig. $1 \mathrm{~A}$ and $\mathrm{B}$ ). The effects more intense were observed in plants that received $250 \mu \mathrm{M} \mathrm{B}+50 \mathrm{mM}$ Ca with increases of $35 \%$ and $40 \%$ in leaf and root, if compared with $25 \mu \mathrm{M} \mathrm{B}+5 \mathrm{mM} \mathrm{Ca}$ treatment. To EL were observed similar behaviors in leaf and root, being detected to $250 \mu \mathrm{M} \mathrm{B}+50 \mathrm{mM} \mathrm{Ca}$ treatment increases of $12 \%$ and $22 \%$ in leaf and root, respectively, when compared with $25 \mu \mathrm{M} \mathrm{B}+5 \mathrm{mM} \mathrm{Ca}$ (Fig. $1 \mathrm{C}$ and D).

\section{Interference of $\mathrm{B}$ and $\mathrm{Ca}$ on gas exchange}

The $\mathrm{P}_{\mathrm{N}}$ decreased significantly with applications combined of $250 \mu \mathrm{M} \mathrm{B}+50 \mathrm{mM} \mathrm{Ca}$, being verified a reduction of $44 \%$, compared with $25 \mu \mathrm{M} \mathrm{B}+5 \mathrm{mM} \mathrm{Ca}$ (Fig. $2 \mathrm{~A}$ ). To $\mathrm{g}_{\mathrm{s}}$ was observed a decrease of approximately $35 \%$ (Fig. 2 B) in the plants that received $250 \mu \mathrm{M} \mathrm{B}+5 \mathrm{mM}$ Ca comparing with control $(25 \mu \mathrm{M} \mathrm{B}+5 \mathrm{mM} \mathrm{Ca})$. Results linked to E shown that plants had an increase of $13 \%$ (non-significant) with the high availability of $\mathrm{B}$ and $\mathrm{Ca}$ in the solution (Fig. 2 C). The $\mathrm{C}_{\mathrm{i}}$ was decreased by $14 \%$ in treatment that used $250 \mu \mathrm{M} \mathrm{B}+50 \mathrm{mM} \mathrm{Ca}$, however was not sufficient to differ $25 \mu \mathrm{M} \mathrm{B}+5 \mathrm{mM} \mathrm{Ca}$ treatment (Fig. $2 \mathrm{D})$. The $\mathrm{P}_{\mathrm{N}} / \mathrm{C}_{\mathrm{i}}$ also dramatically reduced with $250 \mu \mathrm{M} \mathrm{B}+50 \mathrm{mM}$ $\mathrm{Ca}(34 \%)$, when compared with $25 \mu \mathrm{M} \mathrm{B}+5 \mathrm{mM} \mathrm{Ca}$ (Fig. 2 E). Similar behavior was observed in WUE, reduced $51 \%$ with $250 \mu \mathrm{M} \mathrm{B}+50 \mathrm{mM} \mathrm{Ca}$ (Fig. 2 F).

Reductions promoted by high B and Ca on chlorophylls The CHL a presented significant reductions, being the most severe occurred when there was an increase in availability of $\mathrm{B}$ and $\mathrm{Ca}(250 \mu \mathrm{M} \mathrm{B}+50 \mathrm{mM} \mathrm{Ca})$, with decrease

Table 1: Content and accumulation of $\mathrm{B}$ and $\mathrm{Ca}$ in young $S$. parahyba plants subjected to different of $\mathrm{B}$ and Ca supplies. Columns with different letters next to treatments indicate significant differences from the Skott-Knott test $(P<0.05)$. Values described corresponding to means and standard deviations from five repetitions.

\begin{tabular}{|c|c|c|c|c|c|c|}
\hline \multirow[t]{2}{*}{ Trataments } & \multicolumn{3}{|c|}{ B content $\left(\mathrm{mg} \mathrm{kg}^{-1}\right)$} & \multicolumn{3}{|c|}{ B accumulation $\left(\mathrm{mg} \mathrm{g}^{-1}\right)$} \\
\hline & Leaf & Stem & Root & Leaf & Stem & Root \\
\hline $25 \mu \mathrm{M} \mathrm{B}+5 \mathrm{mM} \mathrm{Ca}$ & $127.89 \pm 12.04 \mathrm{c}$ & $30.36 \pm 2.93 a$ & $36.69 \pm 3.32 \mathrm{c}$ & $623.75 \pm 57.53 \mathrm{c}$ & $118.43 \pm 9.65 b$ & $73.33 \pm 4.53 \mathrm{c}$ \\
\hline $25 \mu \mathrm{M} \mathrm{B}+50 \mathrm{mM} \mathrm{Ca}$ & $81.92 \pm 8.03 d$ & $26.57 \pm 1.16 b$ & $28.50 \pm 2.37 d$ & $400.64 \pm 38.52 d$ & $86.25 \pm 6.49 c$ & $54.02 \pm 4.93 d$ \\
\hline $250 \mu \mathrm{M} \mathrm{B}+5 \mathrm{mM} \mathrm{Ca}$ & $178.12 \pm 16.88 b$ & $32.69 \pm 2.97 a$ & $47.99 \pm 1.39 a$ & $877.45 \pm 82.59 b$ & $131.53 \pm 9.04 b$ & $91.23 \pm 5.87 b$ \\
\hline \multirow[t]{3}{*}{$250 \mu \mathrm{M} \mathrm{B}+50 \mathrm{mM} \mathrm{Ca}$} & $240.33 \pm 18.62 a$ & $29.25 \pm 2.76 a$ & $42.35 \pm 1.01 b$ & $1419.73 \pm 129.91 a$ & $167.06 \pm 13.58 \mathrm{a}$ & $116.72 \pm 10.89 a$ \\
\hline & \multicolumn{3}{|c|}{ Ca Content $\left(\mathrm{g} \mathrm{kg}^{-1}\right)$} & \multicolumn{3}{|c|}{ Ca accumulation $\left(\mathrm{g} \mathrm{g} \mathrm{g}^{-1}\right)$} \\
\hline & Leaf & Stem & Root & Leaf & Stem & Root \\
\hline $25 \mu \mathrm{M} \mathrm{B}+5 \mathrm{mM} \mathrm{Ca}$ & $5.08 \pm 0.10 a$ & $2.19 \pm 0.20 \mathrm{a}$ & $7.33 \pm 0.41 a$ & $25.26 \pm 2.46 b$ & $8.55 \pm 0.81 b$ & $14.73 \pm 1.05 b$ \\
\hline $25 \mu \mathrm{M} \mathrm{B}+50 \mathrm{mM} \mathrm{Ca}$ & $5.08 \pm 0.44 a$ & $2.33 \pm 0.20 \mathrm{a}$ & $7.25 \pm 0.31 a$ & $24.69 \pm 2.39 b$ & $7.56 \pm 0.71 \mathrm{c}$ & $13.71 \pm 0.97 b$ \\
\hline $250 \mu \mathrm{M} \mathrm{B}+5 \mathrm{mM} \mathrm{Ca}$ & $5.00 \pm 0.35 a$ & $1.75 \pm 0.11 b$ & $6.33 \pm 0.10 \mathrm{~b}$ & $24.72 \pm 2.45 b$ & $7.04 \pm 0.68 c$ & $12.07 \pm 1.19 \mathrm{c}$ \\
\hline $250 \mu \mathrm{M} \mathrm{B}+50 \mathrm{mM} \mathrm{Ca}$ & $5.17 \pm 0.41 a$ & $2.08 \pm 0.10 a$ & $6.17 \pm 0.27 \mathrm{~b}$ & $30.46 \pm 2.99 a$ & $11.91 \pm 1.08 a$ & $16.97 \pm 1.23 a$ \\
\hline
\end{tabular}




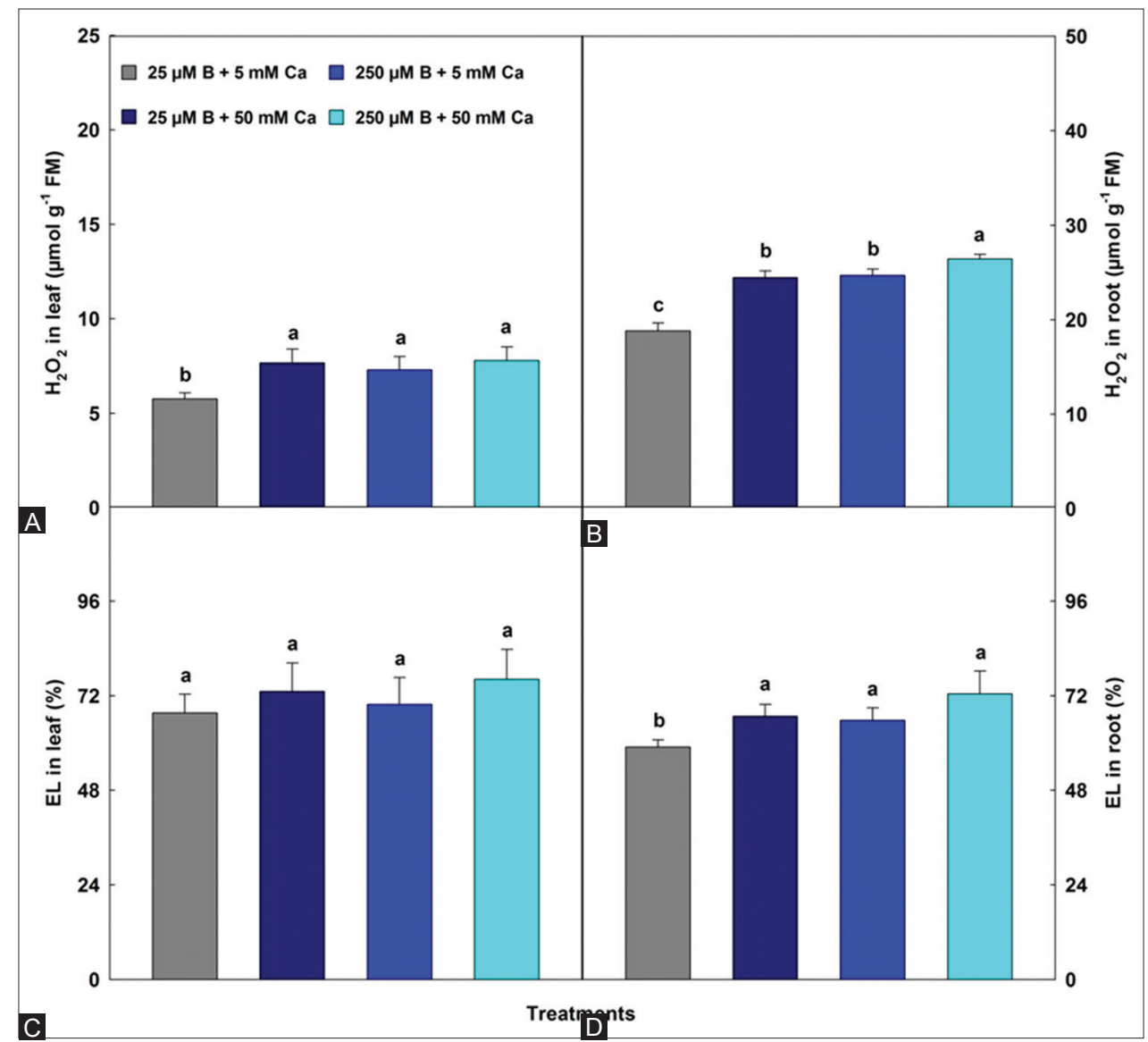

Fig 1. Hydrogen peroxide in leaf $(A)$ hydrogen peroxide in the root $(A)$, electrolyte leakage in leaf $(C)$ and electrolyte leakage in root $(D)$ in young S. parahyba plants subjected to different of $B$ and $C a$ supplies. Bars with different letters indicate significant differences from the Skott-Knott test $(P<0.05)$. Bars represent the mean values and error bars represent the standard deviations from five replicates.

of $42 \%$ compared with control plants (Fig. 3 A). The concentration of CHL b decreased 7\% (non-significant) after the excessive application of B and Ca (Fig. 3 B). Total CHL rate had a significant reduction of $32 \%$ when applied $250 \mu \mathrm{M} \mathrm{B}+50 \mathrm{mM}$ Ca compared with control treatment, while applications with $250 \mu \mathrm{M} \mathrm{B}+5 \mathrm{mM} \mathrm{Ca}$, and $25 \mu \mathrm{M}$ $\mathrm{B}+50 \mathrm{mM}$ Ca presented reductions of $27 \%$ and $15 \%$, respectively (Fig. $3 \mathrm{C}$ ). The CAR in plants submitted to high $\mathrm{B}$ and $\mathrm{Ca}(250 \mu \mathrm{M} \mathrm{B}+50 \mathrm{mM} \mathrm{Ca})$, suffered the strong increase $(147 \%)$ comparison with control treatment (Fig. 3 D).

\section{ASC and GSH total had different behaviors after B and $\mathrm{Ca}$ supplies}

There were significant changes in the ASC content in the leaves and roots with the combinations of $\mathrm{B}$ and $\mathrm{Ca}$ (Fig. 4 $A$ and B), being observed increase of $187 \%$ and $85 \%$ in leaf and root after application of $250 \mu \mathrm{M} \mathrm{B}+50 \mathrm{mM} \mathrm{Ca}$ when compared to control. The combination of $\mathrm{B}$ and Ca caused a reduction in GSH levels in the leaf and root, showing greater reduction when $\mathrm{B}$ and $\mathrm{Ca}$ were in excess, with $24 \%$ and $55 \%$ in leaf and root compared to control (Fig. 4 C E D).

\section{$B$ and $\mathrm{Ca}$ levels on growth}

High B and Ca supplies applied resulted in negative effects on plant growth. In relation to stem diameter was not verified significant modifications promoted by the $\mathrm{B}$ and Ca supplies. Total dry matter had significant decreases when applied $250 \mu \mathrm{M} \mathrm{B}+50 \mathrm{mM}$ Ca treatment, being $21 \%$ and $14 \%$ in leaf and total, respectively, compared with $25 \mu \mathrm{M}$ $\mathrm{B}+5 \mathrm{mM} \mathrm{Ca}$ (Table 2). The quality index of S. parahyba seedlings decreased with the application of high $\mathrm{B}$ and $\mathrm{Ca}$, but all seedlings are above standard of quality established by Dickson et al. (1960) for seedlings.

\section{DISCUSSION}

Contents and accumulation of B and $\mathrm{Ca}$ increased in treatments exposed to high $\mathrm{B}$ and $\mathrm{Ca}$ levels in nutrient solution, because the transpiration rate was not affected. These nutrients are normally distributed in plants tissues, being both ( $\mathrm{B}$ and $\mathrm{Ca}$ ) transported mainly by the mass flow. Siddiqui et al. (2013) observed that the application together $\mathrm{B}$ and $\mathrm{Ca}$ were more effective than isolated in the improvement of plant growth. 


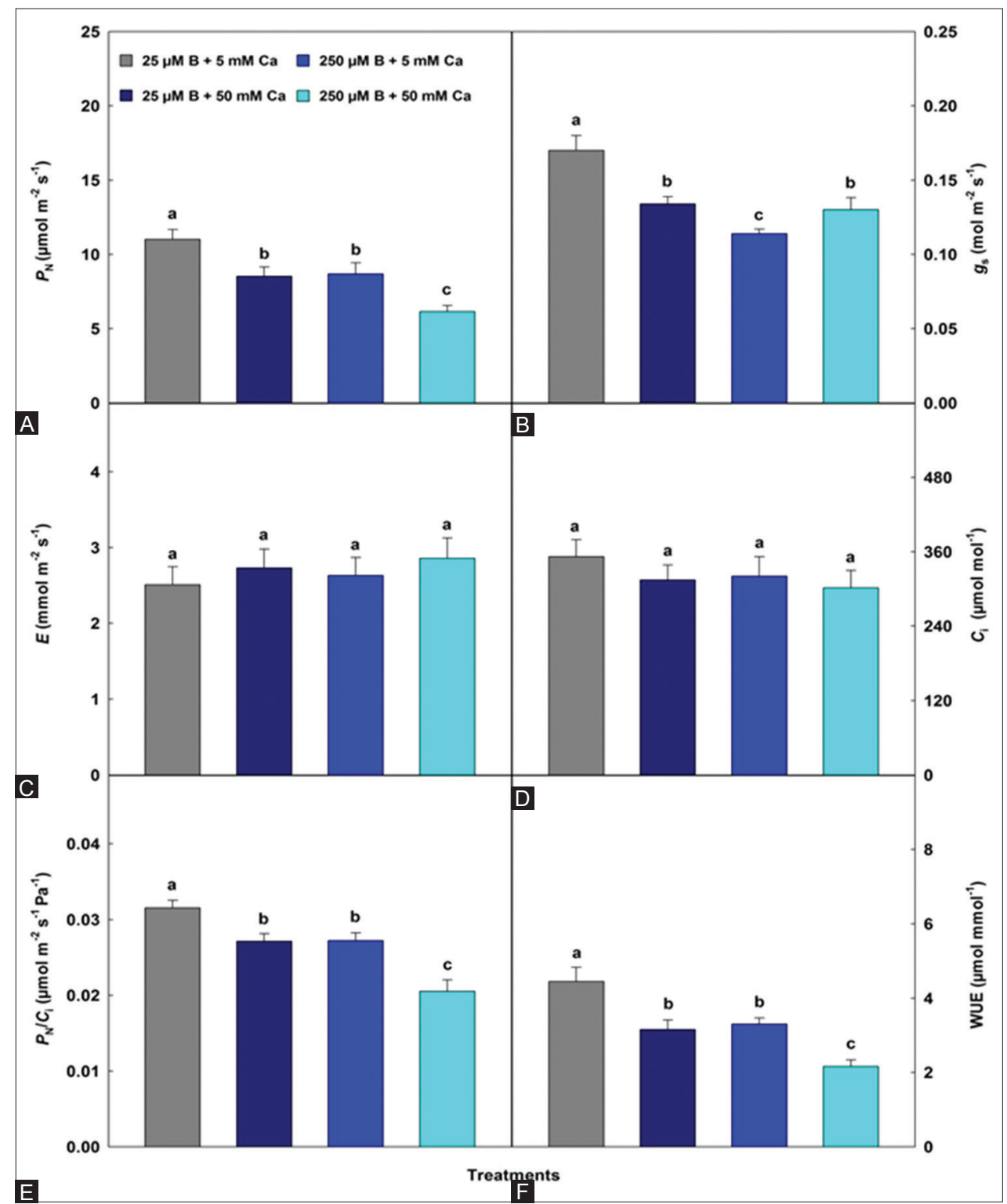

Fig 2. Net photosynthetic rate (A), stomatal conductance (B), transpiration rate $(C)$ intercellular $C O 2$ concentration, (D) efficiency of instantaneous carboxylation $(E)$, and water use efficiency $(F)$ in young $S$. parahyba plants subjected to different of $B$ and Ca supplies. Bars with different letters indicate significant differences from the Skott-Knott test $(P<0.05)$. Bars represent the mean values and error bars represent the standard deviations from five repetitions.

Table 2: Stem diameter, dry matter and Dickson quality index (DQI) in young S. parahyba plants subjected to different of B and Ca supplies. Columns with different letters next to treatments indicate significant differences from the Skott-Knott test $(P<0.05)$. Values described correspond to means and standard deviations from five repetitions.

\begin{tabular}{|c|c|c|c|c|c|c|}
\hline \multirow[t]{2}{*}{ Treatments } & \multirow[t]{2}{*}{ Stem diameter $(\mathrm{cm})$} & \multicolumn{4}{|c|}{ Dry matter $\left(p\right.$ plant $\left.^{-1}\right)$} & \multirow[t]{2}{*}{ DQI } \\
\hline & & Stem & Leaf & Root & Total & \\
\hline $25 \mu \mathrm{M} \mathrm{B}+5 \mathrm{mM} \mathrm{Ca}$ & $6.58 \pm 0.65 a$ & $3.92 \pm 0.37 a$ & $4.97 \pm 0.46 a$ & $2.01 \pm 0.17 a$ & $10.90 \pm 0.51 a$ & $1.13 \pm 0.19 a$ \\
\hline $25 \mu \mathrm{M} \mathrm{B}+50 \mathrm{mM} \mathrm{Ca}$ & $6.87 \pm 0.50 \mathrm{a}$ & $3.85 \pm 0.24 a$ & $4.87 \pm 0.47 a$ & $1.99 \pm 0.13 a$ & $10.71 \pm 0.44 a$ & $1.24 \pm 0.17 a$ \\
\hline $250 \mu \mathrm{M} \mathrm{B}+5 \mathrm{mM} \mathrm{Ca}$ & $6.81 \pm 0.70 a$ & $3.42 \pm 0.35 a$ & $4.94 \pm 0.36 a$ & $1.90 \pm 0.16 \mathrm{a}$ & $10.26 \pm 0.43 a$ & $1.23 \pm 0.25 a$ \\
\hline $250 \mu \mathrm{M} \mathrm{B}+50 \mathrm{mM} \mathrm{Ca}$ & $5.91 \pm 0.72 a$ & $3.71 \pm 0.55 a$ & $3.90 \pm 0.34 b$ & $1.75 \pm 0.21 \mathrm{a}$ & $9.36 \pm 0.32 b$ & $0.99 \pm 0.12 \mathrm{a}$ \\
\hline
\end{tabular}

The $\mathrm{H}_{2} \mathrm{O}_{2}$ were increased in the leaves and roots, and these results are related to oxidative stress caused by the $\mathrm{B}$ and Ca excess in solution (Esim et al., 2012; Blasco et al., 2014.). Siddiqui et al. (2013) studying Raphanus sativus submitted the interaction of $\mathrm{B}$ and $\mathrm{Ca}$ toxic observed similar behavior to this study. To EL, increases were caused by the $\mathrm{H}_{2} \mathrm{O}_{2}$ accumulation; however this negative effect was more evident in the roots. Excess 


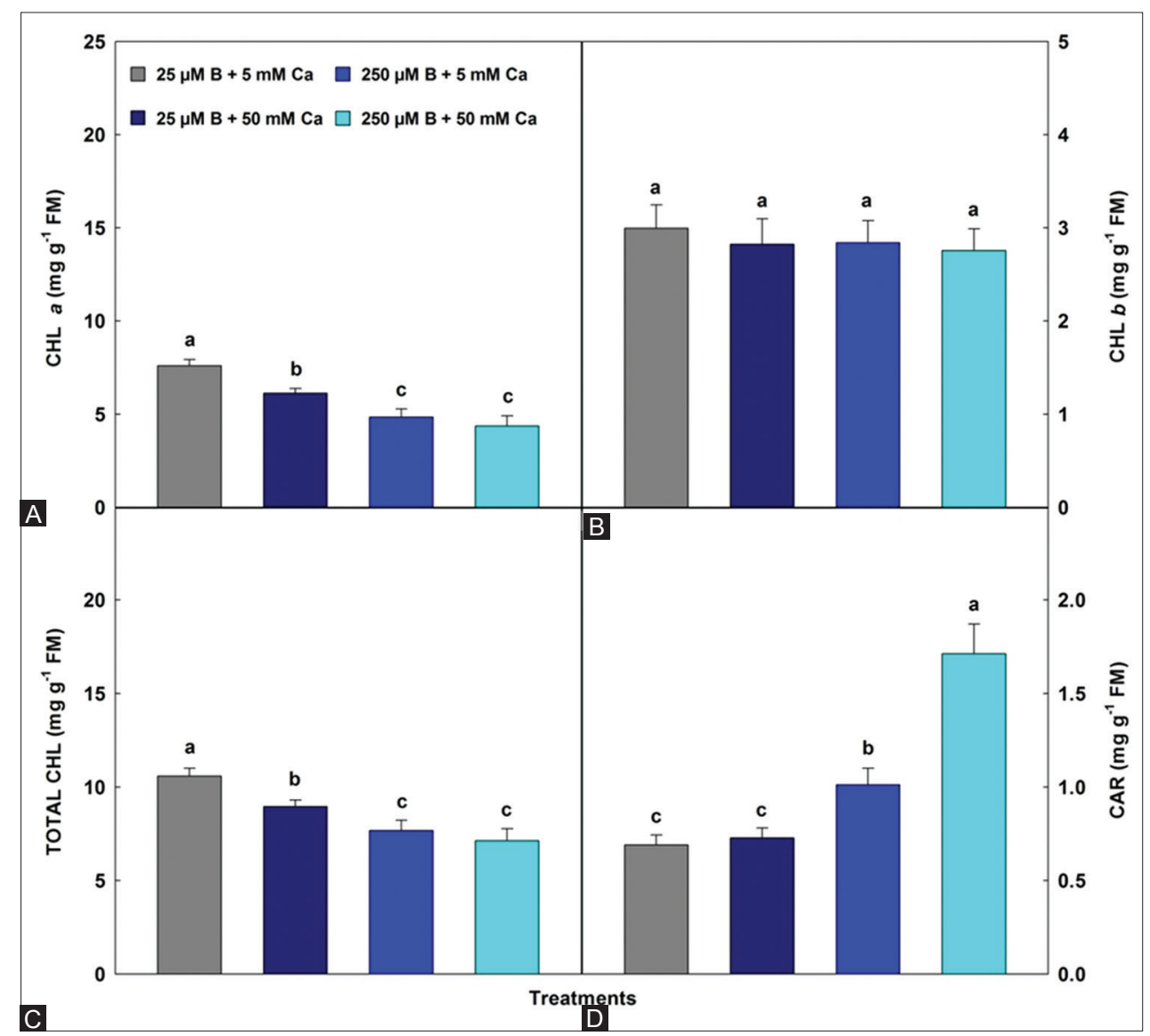

Fig 3. Chlorophyll a (A), chlorophyll b (B), total chlorophyll $(C)$ and carotenoids $(D)$ in young $S$. parahyba plants subjected to different of $B$ and Ca supplies. Bars with different letters indicate significant differences from the Skott-Knott test $(P<0.05)$. Bars represent the mean values and error bars represent the standard deviations from five repetitions.

ROS frequently induces increases in EL (Arbona and Gómez-Cadenas, 2012).

The decrease in $P_{\mathrm{N}}$ is explained by the damages in the chloroplasts due to oxidative stress caused by the combined excess of B and Ca (Landi et al., 2013b and Wang et al., 2010). Chloroplasts are affected by the oxidative stress caused during nutritional imbalance. Hossain et al. (2015) studying the excess B in Brassica napus obtained similar results to this study. In addition, Wang et al. (2010) reported that the excess of $\mathrm{Ca}$ in Camellia sinensis can cause rupture in chloroplast membrane, damages in photosystem II, lower photosynthetic rate and decrease in light capitation.

Reduction in $g_{\mathrm{s}}$ was detected in response to excess of $\mathrm{B}$ and $\mathrm{Ca}$, because the high $\mathrm{B}$ in leaf directly affects the stomatal mechanism (Apostol and Zwiazek, 2004). Mattiello et al. (2009) studying the effect of excess B in E. grandis clones, observed decrease in $g_{\mathrm{s}}$, corroborating with the results of this study. Cabañero and Carvajal (2007) also observed this behavior in Capsicum annum L. plant with the excess Ca.

In relation to $E$ and $C_{i}$, these variables presented not significant changes, corroborating with the study by Huang et al. (2014) who also did not found modification in $E$ of Citrus sinensis under B excess. Papadakis et al. (2004) studying the B toxicity effects in Citrus plants observed decreased in $P_{\mathrm{N}} / C_{\mathrm{i}}$, similar with results detected in this research. Reduction in WUE is related to decrease in $P_{\mathrm{N}}$ caused during excessive nutrient supply. Hosaini et al. (2009) applied $30 \mathrm{mg} \mathrm{kg}^{-1}$ of B in the soil and observed that the WUE decreased in Brassica napus plants.

The decrease in CHL $a$, and Total CHL occurred due to lower biosynthesis of precursors of chlorophylls during high $\mathrm{B}$ and $\mathrm{Ca}$ concentrations. $\mathrm{B}$ when in excess provides increases of the phenolic compounds by the action of peroxidase enzyme, and high levels of $\mathrm{Ca}$ affect absorption and $\mathrm{Ca}$ and $\mathrm{Mg}$ distributions in plant, both actions result in the chlorophyll degradation (Pandey, 2013; Seth and Aery, 2014; Jiazhi et al., 2014.). Similar results were described by Landi et al. (2013b) working with Cucurbita pepo with B excess. Jiazhi et al. (2014) observed that the high Ca reduced the pigments levels in Camellia sinensis plants, corroborating with the results of this study.

The increase in CAR was due to protection mechanism against the stress caused by the high availability of $\mathrm{B}$ and 


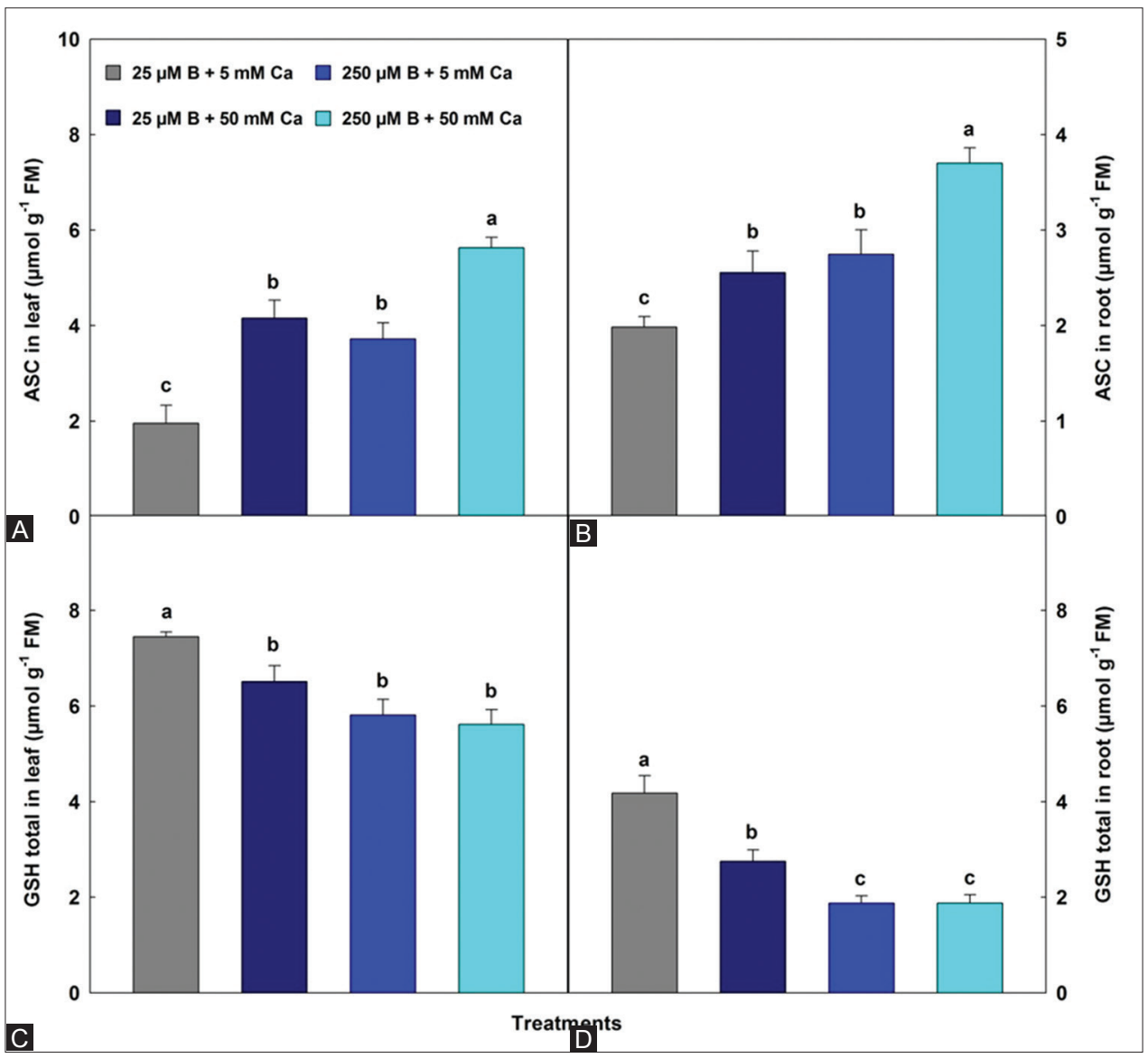

Fig 4. Ascorbate in leaf (A), ascorbate in root (B), glutathione total in leaf (C) and glutathione total in root (D) in young $S$. parahyba plants subjected to different of B and Ca supplies. Bars with different letters indicate significant differences from the Skott-Knott test $(P<0.05)$. Bars represent the mean values and error bars represent the standard deviations from five repetition.

Ca. In agreement with Nisar et al. (2015), this pigment has an essential role in photoprotection, in which this protects the photosynthetic apparatus. These results corroborate the study of Cervilla et al. (2012) when studied the B effect in Solanum lycopersicum plants and Danieli et al. (2002) working with Diospyros kaki plants under high Ca.

The ASC increases in leaf and root tissues are related to the oxidative stress. Similar results were observed by Cervilla et al. (2007) studying B toxicity in Solanum lycopersicum plants. To GSH total were verified decrease and this effect was caused by the increase in B treatment, which contributed to inefficient performance of the antioxidant system (Silva et al., 2016). In agreement with Ruiz et al. (2003) the B toxicity inhibits the conversion of cysteine for GSH, this fact is considered the main reason of the phytotoxicity in Helianthus annus plants. et al. (2009) obtained similar behavior in Citrus sinensis plants in response to B toxicity.

High availability B and Ca promoted decreases the plant growth, represented by lower values of SD, LDM, SDM, RDM, TDM and DQI, this fact can be explained by the imbalance nutritional. Ramos et al. (2013) evaluating the
$\mathrm{Ca} / \mathrm{B}$ ratio in Eucalyptus citriodora plants detected that the $\mathrm{B}$ application without a suitable supply of $\mathrm{Ca}$ can lead to an imbalance between these nutrients affecting plant nutrition and growth. Turan et al. (2009) studying the effect of these nutrients in Triticum aestivum plants observed results similar corroborating with this study.

Negative impacts on gas exchange, photosynthetic pigments and total glutathione were obtained, besides increases in hydrogen peroxide and electrolyte leakage were verified in plants treated with $\mathrm{B}$ and $\mathrm{Ca}$ high, indicating oxidative stress. Thus, application $250 \mu \mathrm{M} \mathrm{B}$ combined with $50 \mathrm{mM}$ Ca promoted disorders in plant metabolism, decreasing the growth and quality of young Schizolobium parabyba plants.

\section{ACKNOWLEDGEMENTS}

This research had financial support Conselho Nacional de Desenvolvimento Científico e Tecnológico (CNPq/Brasil), Fundação Amazônia Paraense de Amparo à Pesquisa (FAPESPA) and Universidade Federal Rural da Amazônia (UFRA) to Lobato E. M. S. G. and Callegari D. M. were 
supported by undergraduate scholarships also from Conselho Nacional de Desenvolvimento Científico e Tecnológico (CNPq/Brazil).

\section{Author contributions}

Lobato E.M.S.G. was the advisor of this project and planned all phases of this research. Callegari D.M., Silva B.C., Sousa P.R., Lobato A.K.S. conducted the experiment in the greenhouse and performed physiological, biochemical and morphological determinations, as well as interpreted the results and wrote the manuscript.

\section{REFERENCES}

Apostol, K. G. and J. J. Zwiazek. 2004. Boron and water uptake in jack pine (Pinus banksiana) seedlings. Environ. Exp. Bot. 51: 145-153.

Aragão, R. M., E. N. Silva, C. F. Vieira and J. A. G. Silveira. 2012. High supply of $\mathrm{NO}_{3}{ }^{-}$mitigates salinity effects through an enhancement in the efficiency of photosystem II and $\mathrm{CO}_{2}$ assimilation in Jatropha curcas plants. Acta Physiol. Plant. 34(6): 2135-2143.

Arbona, V. and A. Gómez-Cadenas. 2012. Antioxidant system in citrus under nutrient stress conditions: Latest developments. In: A. K. Srivastava (Ed.), Advances in Citrus Nutrition, SpringerVerlag, Spain, pp. 13-24.

Blasco, B., N. S. Graham and M. R. Broadley. 2014. Antioxidant response and carboxylate metabolism in Brassica rapa exposed to different external Zn, Ca and Mg supply. J. Plant Physiol. 176: 16-24.

Cabañero, F. J. and M. Carvajal. 2007. Different cation stresses affect specifically osmotic root hydraulic conductance, involving aquaporins, ATPase and xylem loading of ions in Capsicum annuum, L. plants. J. Plant Physiol. 164: 1300-1310.

Cakmak, I. and H. Marschner. 1992. Magnesium deficiency and high light intensity anhance activities of superoxide dismutase, ascorbate peroxidase, and glutathione reductase in bean leaves. Plant Physiol. 98: 1222-1227.

Cervilla, L. M., B. A. Blasco, J. J. Ríos, L. Romero and J. M. Ruiz. 2007. Oxidative stress and antioxidants in tomato (Solanum lycopersicum) plants subjected to boron toxicity. Ann. Bot. 100: 747-756.

Cervilla, L. M., B. A. Blasco, J. J. Ríos, M. A. Rosales, E. SánchezRodríguez, M. M. Rubio-Wilhelmi, L. Romero and J. M. Ruiz. 2012. Parameters symptomatic for boron toxicity in leaves of tomato plants. J. Bot. 2012: 1-17.

Danieli, R., C. L. Girardi, A. Parussolo, V. C. Ferri and C. V. Rombaldi. 2002. Effect of the application of gibberellic acid and calcium chloride in the retardation of harvest and conservability of persimmon, fuyu. Rev. Bras. Fruticultura. 24(1): 44-48.

Dayod, M., S. D. Tyerman, R. A. Leight and M. Gilliham. 2010. Calcium storage in plants and the implications for calcium biofortification. Protoplasma. 247: 215-231.

Dickson, A., A. L. Leaf and J. F. Hosner. 1960. Quality appraisal of white spruce and white pine seedling stock in nurseries. For. Chron. 36: 10-13.

Esim, N., D. Tiryaki, O. Karadagoglu and O. Atici. 2012. Toxic effects of boron on growth and antioxidant system parameters of maize (Zea mays L.) roots. Toxicol. Ind. Health. 29: 800-805.

Gong, M., Y. J. Li and S. Z. Chen. 1998. Abscisic acid-induced thermotolerance in maize seedilings is mediated by calcium and associated with antioxidant systems. J. Plant Physiol. 153(3-4): 488-496.

Gunes, A., G. Soylemezoglu, A. Inal, E. G. Bagci, S. Coban and O. Sahin. 2006. Antioxidant and stomatal responses of grapevine (Vitis vinifera L.) to boron toxicity. Sci. Hortic. 110: 279-284.

Hoagland, D. R., and Arnon, D. I. 1950. The Water Culture Method for Growing Plants Without Soil. California Agricultural Experiment Station, San Francisco.

Hosaini, Y., M. Homaee, N. A. Karimian and S. Saadat. 2009. Modeling vegetative stage response of canola (Brassica napus L.) to combined salinity and boron tresses. Int. J. Plant Prod. 3(1): 91-104.

Hossain, M. F., P. Shenggang, D. Meiyang, M. Zhaowen, M. B. Karbo, A. Bano and T. Xiangru. 2015. Photosynthesis and antioxidant response to winter rapeseed (Brassica napus L.) as affected by boron. Pak. J. Bot. 47(2): 675-684.

Huang, J. H., Z. J. Cai, S. X. Wen, P. Guo, X. Ye, G. Z. Lin and L. S. Chen. 2014. Effects of boron toxicity on root and leaf anatomy in two Citrus species differing in boron tolerance. Trees. 28(6): 1653-1666.

Jiazhi, S., X. Zhang, Y. Wang and J. Hu. 2014. Dynamic effects of excessive calcium on chlorophyll composition and calcium and magnesium absorption of tea seedlings. Shandong Agric. Sci. 6: $85-88$.

Kaya, C. and M. Ashraf. 2015. Exogenous application of nitric oxide promotes growth and oxidative defense system in highly boron stressed tomato plants bearing fruit. Sci. Hortic. 185: 43-47.

Landi, M., D. Remorini, A. Pardossi and L. Guidi. 2013a. Purple versus green-leafed Ocimum basilicum: Which differences occur with regard to photosynthesis under boron toxicity? J. Plant Nutr. Soil Sci. 176: 942-951.

Landi, M., D. Remorini, A. Pardossi and L. Guidi. 2013b. Boron excess affects photosynthesis and antioxidant apparatus of greenhouse Cucurbita pepo and Cucumis sativus. J. Plant Res. 126: $775-786$

Lautner, S., B. Ehlting, E. Windeisen, H. Rennenberg, R. Matyssek and J. Fromm. 2007. Calcium nutrition has a significant influence on wood formation in poplar. New Phytol. 174: 743-752.

Lehto, T., T. Ruuhola and B. Dell. 2010. Boron in forest trees and forest ecosystems. For. Ecol. Manage. 260: 2053-2069.

Li, W., F. Xu, S. Chen, Z. Zhang, Z. Zhao, Y. Jin, M. Li, Y. Zhu, Y. Liu, Y. Yang and X. Deng. 2014. A comparative study on Ca contente and distribution in two Gesneriacea species reveals distinctive mechanisms to cope with high rhizospheric soluble calcium. Front. Plant Sci. 5: 1-14.

Lichtenthaler, H. K. and C. Buschmann. 2001. Chlorophylls and carotenoids: Measurement and characterization by UV-VIS spectroscopy. Current Protocols in Food Analytical Chemistry, John Wiley and Sons, Hoboken, pp. 431-438.

Ma, J. F., N. Mitani, S. Nagao, S. Konishi, K. Tamai, T. Iwashita and M. Yano. 2004. Characterization of the silicon uptake system and molecular mapping of the silicon transporter gene in rice. Plant Physiol. 136(2): 3284-3289.

Malavolta, E., G. C. Vitti and S. A. Oliveira. 1997. Avaliação do Estado Nutricional das Plantas: Princípios e Aplicações, $2^{\text {th }}$ ed, Potafós, Piracicaba.

Martinez-Cuenca, M. R., B. Martínez-Alcántara, A. Quinones, M. Ruiz, D. J. Iglesias, E. Primo-Millo and M. A. Forner-Giner. 2015. Physiological and molecular responses to excess Boron in Citrus macrophylla W. PLos One. 10: 1-18.

Mattiello, E. M., H. A. Ruiz, I. R. Silva, P. C. Guerra and V. M. Andrade. 2009. Physiological characteristics and dry matter production of 
eucalyptus in response to boron. Ver. Árvore. 33: 821-830.

Molassiotis, A., T. Sotiropoulos, G. Tanou, G. Diamantidis and I. Therious. 2006. Boron-induced oxidative damage and antioxidant and nucleolytic responses in shoot tip cultures of apple rootstock EM 9 (Malus domestica Borkh). Environ. Exp. Bot. 56(1): 54-62.

Nisar, N., L. Li, S. Lu, N. C. Khin and B. J. Pogson. 2015. Carotenoid metabolism in plants. Mol. Plant. 8(1): 68-82.

Pandey, N. A. 2013. Antioxidant responses and water status in Brassica seedlings subjected to boron stress. Acta Physiol. Plant. 35(3): 697-706.

Papadakis, I. E., K. N. Dimassi, A. M. Bosabalidis, I. N. Therios, A. Patakas and A. Giannakoula. 2004. Boron toxicity in 'Clementine' mandarin plants grafted on two rootstocks. Plant Sci. 166(2): 539-547.

Ramos, S. J., V. Faquin, F. W. Ávila, R. M. A. Ferreira and J. L. Araújo. 2013. Biomass production, $B$ accumulation and $C a / B$ ratio in Eucalyptus under various conditions of water availability and $\mathrm{B}$ doses. Cerne. 19(2):289-295.

Ruiz, J. M., R. M. Rivero and L. Romero. 2003. Preliminary studies on the involvement of biosynthesis of cysteine and glutathione concentration in the resistance to B toxicity in sunflower plants. Plant Sci. 165(4): 811-817.

Seth, K. and N. C. Aery. 2014. Effect of boron on the contents of chlorophyll, carotenoid, phenol and soluble leaf protein in mung bean, Vigna radiata (L.) Wilczek. Proc. Natl. Acad. Sci. India Sect. B Biol. Sci. 84(3): 713-719.
Siddiqui, M. H., M. H. Al-Whaibi, A. M. Sakran, H. M. Ali, M. O. Basalah, M. Faisal, A. Alatar and A. A. Al-Amri. 2013. Calciuminduced amelioration of boron toxicity in radish. J. Plant Growth Regul. 32(1): 61-71.

Silva, P. F. N., E. M. S. Guedes, P. R. Souza, H. J. S. Santos, R. O. Braga, A. S. Moura and A. K. S. Lobato. 2016. Proline but not glutathione actively participates in the tolerance mechanism of young Schizolobium parahyba var. amazonicum plants exposed to boron toxicity. Not. Bot. Horti. Agrobot. Cluj Napoca. 44(1): 215-221.

Turan, M. A., N. Taban and S. Taban. 2009. Effect of calcium on the alleviation of boron toxicity and localization of boron and calcium in cell wall of wheat. Not. Bot. Horti. Agrobot. Cluj Napoca. 37(2): 99-103.

Velikova, V., I. Yordanov and A. Edreva. 2000. Oxidative stress and some antioxidant systems in acid rain-treated bean plants: Protective role of exogenous polyamines. Plant Sci. 151(1): 59-66.

Wang, Y. H., L. X. Zhang and Q. Y. Sun. 2010. Effect of excessive calcium fertilization on photosynthetic characteristics and chloroplast ultra-structure of tea tree. Plant Nutr. Fert. Sci. 16(2): 432-438.

White, P. J. and M. R. Broadley. 2003. Calcium in plants. Ann. Bot. 92(4): 487-511.

Wu, Q. S., R. X. Xia and Y. N Zou. 2006. Reactive oxygen metabolism in mycorrhizal and non-mycorrhizal citrus (Poncirus trifoliata) seedlings subjected to water stress. J. Plant Physiol. 163(11): 1101-1110. 